\title{
Pengembangan Modul Konsep Mol Berbasis Inkuiri Terstruktur dengan Penekanan Pada Interkoneksi Tiga Level Representasi Kimia Untuk Kelas X SMA
}

\author{
Randa Sagita ${ }^{1)}$ Fajriah Azra ${ }^{2)}$ Minda Azhar ${ }^{3 *}$ \\ ${ }^{1)}$ Jurusan Kimia, FMIPA Universitas Negeri Padang \\ ${ }^{2)}$ Jurusan Kimia, FMIPA Universitas Negeri Padang \\ ${ }^{3)}$ Jurusan Kimia, FMIPA Universitas Negeri Padang \\ Email $^{3^{*}}$ : minda@fmipa.unp.ac.id
}

\begin{abstract}
The research has created the module of mole concept based on structured inquiry with interconnection of multiple representation and determined the validity and practicality of the module. The research type was Research and Development $(R \& D)$. The development model was 4-D models that consist of four steps: define, design, develop, and disseminate. The research was limited on develop step. The instrument of the research was questionnaire form that consist of validity and practicality sheets. The module was validated by 5 validators. Practicality module was tested by 2 chemistry teachers and 28 students of grade XI MIA 5 at SMAN 4 of Padang. Validity and practicality data were analysed by using the kappa Cohen formula. The moment kappa average of 5 validators was 0,95 with highest validity category. The moment kappa average of teachers and students were 0,89 and 0,91 praticality with high category. The result of the research showed that the module of mole concept based on structured inquiry with interconnection of macro, submicro, and symbolic representation was valid and practice to be used on the learning chemistry.
\end{abstract}

Keywords : Structured inquiry, Multiple representation, Mole concept, 4-D model

This is an open access article distributed under the Creative Commons 4.0 Attribution License, which permits unrestricted use, distribution, and reproduction in any medium, provided the original work is properly cited 12018 by author and Universitas Negeri Padang.

\section{PENDAHULUAN}

Pada dasarnya ilmu kimia menjelaskan tentang susunan, komposisi, sifat-sifat dan perubahan materi serta perubahan energi yang menyertainya (Brady, 2012). Salah satu materi pelajaran kimia yang dipelajari di kelas $\mathrm{X}$ adalah konsep mol. Konsep mol mengkaji tentang jumlah partikel. Mol dijadikan sebagai besaran yang menghubungkan satuan massa zat, jumlah partikel, dan volume gas-gas yang terlibat dalam reaksi kimia. Perhitungan kimia akan lebih mudah diterapkan dengan konsep mol.

Dalam proses pembelajaran, bahan ajar yang dipilih dan dikembangkan guru merupakan suatu komponen yang penting untuk menunjang keberhasilan siswa dalam belajar. Bahan ajar adalah segala bentuk bahan atau seperangkat materi yang disusun secara sistematis dan digunakan untuk membantu guru dan siswa dalam melaksanakan kegiatan pembelajaran (Hamdani, 2010). Bahan ajar yang sesuai tentunya menunjang tercapainya tujuan pembelajaran. Salah satu bahan ajar yang bisa dikembangkan adalah modul. Modul merupakan seperangkat bahan ajar yang disajikan secara sistematis sehingga penggunanya dapat belajar dengan atau tanpa seorang fasilitator atau guru (Sabri, 2010). Sebuah modul akan bermakna jika peserta didik dapat menggunakannya dengan mudah. Penggunaan modul dalam proses pembelajaran memungkinkan peserta didik belajar dan menyelesaikan KD lebih cepat. Dengan demikian modul harus disajikan dengan menggunakan bahasa yang mudah dimengerti, menarik dan dilengkapi ilustrasi (Depdiknas, 2008).

Untuk memperoleh bahan ajar yang sesuai, diperlukan pendekatan yang tepat. Menurut kurikulum 2013, pendekatan yang tepat dalam proses pembelajaran adalah pendekatan saintifik. Pendekatan saintifik diyakini sebagai titian emas perkembangan dan pengembangan sikap, keterampilan, dan pengetahuan peserta didik (Kurniasih, 2014). Salah satu model pembelajaran yang sesuai dengan pendekatan saintifik adalah inkuiri.

Berdasarkan tingkat keterlibatan guru dalam proses pembelajaran, model pembelajaran inkuiri terbagi atas inkuiri konfirmasi, inkuiri terstruktur, inkuiri terbimbing dan inkuiri terbuka (Colburn, 2000). Pada inkuiri terstruktur, siswa menyelidiki pertanyaan atau permasalahan yang diberikan oleh guru melalui 
suatu prosedur yang telah ditentukan dan menerima petunjuk dari tiap-tiap prosedur (Bell, 2005). Penelitiaan sebelumnya menyatakan bahwa inkuiri terstruktur dapat meningkatkan pengetahuan siswa terutama pada daya ingat mereka terhadap materi pelajaran. Peserta didik masih dapat mengingat pelajaran meskipun telah berlalu selama 12 minggu (Schmid, 2015). Dalam inkuiri terstruktur, peserta didik melakukan penyelidikan secara langsung dan mengembangkan kemampuan dasarnya dalam penyelidikan, seperti melakukan pengamatan, hipotesis, mengumpulkan dan mengolah data, dan menarik kesimpulan (Zion, 2012).

Beberapa penelitian sebelumnya tentang inkuiri terstruktur, melaporkan bahwa LKS eksperimen dan non-eksperimen berbasis inkuiri terstruktur pada materi kesetimbangan kimia membantu siswa memahami materi dengan baik, melakukan eksperimen, dan meningkatkan hasil belajar siswa (Maryati, 2012). Panduan praktikum kimia berbasis inkuiri terstruktur di kelas XII SMAN 1 Indralaya Utara dapat meningkatkan pemahaman siswa (Ariningsih, 2014). Pembelajaran materi getaran dan gelombang melalui pembelajaran berbasis inkuiri terstruktur dapat meningkatkan minat belajar dan partisipasi aktif siswa (Sugiarto, 2015).

Selain menggunakan model pembelajaran yang tepat, pembelajaran kimia hendaknya ditekankan pada tiga level representasi kimia (makroskopik, submikroskopik, dan simbolik). Pemahaman seseorang terhadap konsep kimia ditentukan oleh kemampuannya dalam mentransfer dan menghubungkan ketiga level representasi tersebut. Saat ini pembelajaran kimia lebih banyak merepresentasikan dua level saja yaitu level makroskopik dan simbolik sedangkan level submikroskopik jarang disentuh. Penelitian sebelumnya menunjukkan ketidakmampuan siswa dalam merepresentasi kan kimia pada level submikroskopik dapat menghambat kemampuannya dalam memecah kan masalah kimia yang berkaitan dengan level makroskopik ataupun simbolik (Sunyono, 2013). Multipel representasi dapat digunakan dalam mempelajari suatu konsep yang rumit dengan penggunaan diagram, grafik, dan persamaan sehingga mempermudah proses pembelajaran (Ainsworth, 2008). Interkoneksi dari ketiga level representasi tersebut adalah salah satu kunci untuk pengajaran kimia (Gilbert and Treagust, 2009).
Memahami ilmu kimia dengan penerapan multiple representasi dapat membantu pengembangan model mental siswa (Chittleborough, 2002). Model mental siswa dapat dibangun melalui pengalaman, interpretasi, dan penjelasan mereka ketika dilibatkan dalam proses pembelajaran. Pengembangan model mental ini diperlukan untuk membuat prediksi, menguji gagasan baru, dan menyelesaikan masalah dalam pembelajaran kimia (Halim, 2013).

Berdasarkan latar belakang di atas, maka penelitian pengembangan bahan ajar materi konsep mol dalam bentuk modul berbasis inkuiri terstruktur dengan penekanan pada interkoneksi tiga level representasi kimia penting dilakukan. Penelitian ini bertujuan untuk menghasilkan modul konsep mol berbasis inkuiri terstruktur dengan penekanan pada interkoneksi tiga level representasi kimia yang valid dan praktis digunakan dalam pembelajaran kimia untuk kelas X SMA.

\section{METODE PENELITIAN}

Jenis dari penelitian ini adalah penelitian dan pengembangan atau Research and Development (R\&D). Penelitian ini dilakukan untuk mengembangkan modul konsep mol berbasis inkuiri terstruktur dengan penekanan pada interkoneksi tiga level representasi kimia untuk kelas X SMA serta mengungkapkan tingkat validitas dan praktikalitas modul tersebut. Instrument yang digunakan dalam penelitian ini adalah angket yang terdiri dari lembar validitas dan lembar praktikalitas. Data yang diperoleh dianalisis menggunakan momen kappa (Boslaugh, 2008).

$$
\mathrm{k}=\frac{\rho-\rho_{\mathrm{e}}}{1-\rho_{\mathrm{e}}}
$$

\section{Keterangan:}

$k=$ Moment kappa yang menunjukkan validitas produk.

$\rho=$ Proporsi yang terealisasi, dihitung dengan cara jumlah nilai yang diberi oleh validator dibagi jumlah nilai maksimal.

$\rho_{\mathrm{e}}=$ Proporsi yang tidak terealisasi, dihitung dengan cara jumlah nilai maksimal dikurangi dengan jumlah nilai total yang diberi validator dibagi jumlah nilai maksimal. 
Tabel 1. Kategori Keputusan Berdasarkan Moment Kappa (k)

\begin{tabular}{|c|c|}
\hline Interval & Kategori \\
\hline $0,81-1,00$ & Sangat tinggi \\
\hline $0,61-0,80$ & Tinggi \\
\hline $0,41-0,60$ & Sedang \\
\hline $0,21-0,40$ & Rendah \\
\hline $0,01-0,20$ & Sangat rendah \\
\hline$\leq 0,00$ & Tidak valid \\
\hline
\end{tabular}

Modul dirancang menggunakan model pengembangan 4-D yang terdiri dari empat tahap pengembangan yaitu, define (pendefinisian), design (perancangan), develop (pengembangan) dan disseminate (penyebaran) (Trianto, 2014). Penelitian ini dibatasi pada tahap develop (pengembangan) yaitu uji validitas dan praktikalitas terhadap produk yang dikembang.

Adapun langkah-langkah yang dilakukan pada penelitian ini adalah sebagai berikut; 1) tahap define (pendefinisian), tahap ini terdiri dari 5 langkah yaitu analisis ujung depan, analisis siswa, analisis tugas, analisis konsep, dan analisis tujuan pembelajaran; 2) tahap design (perancangan), tahap ini bertujuan untuk merancang bahan ajar berupa modul konsep mol berbasis inkuiri terstruktur dengan penekanan pada interkoneksi tiga level representasi kimia untuk kelas X SMA yang terdiri dari tahap observasi, hipotesis, koleksi dan organisasi data, dan kesimpulan. Format penulisan modul disesuaikan dengan panduan pengembangan bahan ajar dari Depdiknas (2008); 3) tahap develop (pengembangan), tahap ini bertujuan untuk menghasilkan modul konsep mol berbasis inkuiri terstruktur dengan penekanan pada interkoneksi tiga level representasi kimia yang valid dan praktis digunakan. Tahap ini terdiri dari uji validitas, revisi, dan praktikalitas.

Instrumen yang digunakan dalam penelitian ini adalah angket validasi dan angket praktikalitas. Angket validasi diberikan kepada dosen kimia FMIPA UNP dan guru kimia SMA sedangkat angket praktikalitas ditujukan kepada guru kimia dan siswa SMA. Angket validasi berguna untuk menilai modul yang dikembangkan dari segi komponen kelayakan isi, komponen penyajian, komponen kebahasaan, dan komponen kegrafikkan. Setelah uji validitas dilakukan, maka dilakukalah revisi terhadap modul yang dikembangkan sesuai dengan saran dari validator. Angket praktikalitas berguna untuk mengetahui tingkat kepraktisan dari penggunaan modul yang dikembangkan.

\section{HASIL DAN PEMBAHASAN}

\section{Hasil Penelitian}

Sesuai dengan tujuan dan prosedur penelitian, telah dihasilkan bahan ajar modul berbasis inkuiri terstruktur dengan penekanan pada interkoneksi tiga level representasi kimia menggunakan model pengembangan 4-D. Hasil yang diperoleh adalah sebagai berikut:

\section{Tahap Define}

Pada tahap define (pendefinisian) diperoleh 5 data yaitu data analisis ujung depan, analisis siswa, analisis tugas, analisis konsep, dan analisis tujuan pembelajaran.

\section{a. Analisis Ujung Depan}

Analisis ujung depan dilakukan dengan mewawancarai beberapa orang guru kimia SMA di kota Padang yaitu SMAN 1 Padang, SMAN 4 Padang, dan SMA Pembangunan Padang. Pada analisis ujung depan diperoleh data bahwa metode yang biasa digunakan guru dalam mengajarkan materi konsep mol adalah metode ceramah. Hal ini dikarenakan materi konsep mol merupakan materi yang terdiri dari rumus-rumus dan perhitungan-perhitungan sehingga guru lebih banyak menjelaskan. Selain itu, sebagian siswa masih mengalami kesulitan dalam memahami materi konsep mol. Jika soal atau latihan yang diberikan kepada siswa divariasikan atau sedikit berbeda dari contoh soal yang dikerjakan, siswa kebingungan menjawab soal atau latihan tersebut. Siswa masih terpaku pada rumus-rumus yang tersedia pada bahan ajar sehingga belum terjadi pembelajaran yang bermakna.

Multipel representasi memberikan fasilitas agar terjadinya belajar bermakna (meaningful learning) atau belajar mendalam (deep learning). Dalam multipel representasi, materi dijelaskan menggunakan informasi verbal dan informasi pictorial yang akan membangun model mental siswa. Siswa akan lebih mudah mengingat pelajaran dan tersimpan pada memori jangka panjang (Schnotz, 2003).

Adapun bahan ajar yang digunakan di sekolah adalah buku, LKS, dan powerpoint. Bahan ajar berupa modul belum tersedia. Modul adalah salah satu bahan ajar yang dapat 
membantu siswa untuk menemukan konsep dan memungkinkan siswa belajar mandiri.

\section{b. Analisis Siswa}

Analisis siswa dilakukan untuk mengetahui karakteristik siswa yang meliputi kemampuan akademik dan motivasi belajar siswa. Secara umum siswa SMA berumur 16-18 tahun. Menurut Piaget, taraf berpikir anak usia 12-18 tahun adalah pada tahap perkembangan operational formal. Pada tahap ini anak sudah mampu berfikir abstrak dan logis serta memiliki kemampuan untuk menafsirkan, mengembang kan hipotesa dan menarik kesimpulan (Budiningsih, 2012).

Berdasarkan hasil wawancara dengan guru kimia diketahui bahwa kemampuan akademik dan motivasi belajar siswa pada materi konsep mol secara umum bersifat heterogen. Ada siswa yang memliki tingkat kemampuan akademik tinggi, sedang, dan rendah. Motivasi belajar siswa dipengaruhi oleh beberapa faktor, salah satunya adalah jam pelajaran. Siswa lebih bersemangat belajar dipagi hari dari pada disiang hari.

Hasil wawancara dengan beberapa siswa menunjukkan bahwa mereka lebih suka proses pembelajaran dengan menggunakan bahan ajar yang menarik yakni bergambar, berwarna, dan disusun menggunakan bahasa yang mudah dipahami.

\section{c. Analisis Tugas}

Analisis tugas mencakup tugas yang dikerjakan siswa dalam pembelajaran sesuai dengan materi yang dipilih yaitu konsep mol. Langkah yang dilakukan pada analisis tugas berupa analisis kompetensi dasar (KD) yang dijabarkan menjadi beberapa indikator pembelajaran dan selanjutnya menjadi tujuan pembelajaran. Kompetensi Dasar materi konsep mol adalah sebagai berikut; 3.11. Menerapkan konsep massa molekul relatif, persamaan reaksi, hukum-hukum dasar kimia dan konsep mol untuk menyelesaikan perhitungan kimia; 4.11. Mengolah dan menganalisis data terkait massa molekul relatif, persamaan reaksi, hukumhukum dasar kimia dan konsep mol untuk menyelesaikan perhitungan kimia.

Kompetensi Dasar tersebut dijabarkan menjadi beberapa indikator yaitu; 1) menjelaskan pengertian mol; 2) menentukan massa molar dan volume molar gas dari suatu senyawa; 3) mengaplikasikan konsep mol dalam menentukan rumus kimia; 4) menentukan rumus senyawa hidrat; 5) menghitung kadar zat dalam campuran seperti (persen, ppm, molaritas, molalitas dan fraksi mol).

Berdasarkan kompetensi dasar dan indikator pembelajaran, dirancang modul konsep mol yang sesuai dengan analisis tugas agar kompetensi yang diharapkan dapat dicapai siswa pada akhir pembelajaran.

\section{d. Analisis Konsep}

Konsep-konsep pada materi ini disusun dalam bentuk hirearki konsep. Adapun konsepkonsep tersebut adalah konsep mol, massa molar, volume molar, rumus empiris, rumus molekul, rumus senyawa hidrat, dan kadar zat. Konsep-konsep tersebut dianalisis berdasarkan buku-buku kimia perguruan tinggi dan buku kimia SMA yang relevan.

\section{e. Analisis Tujuan Pembelajaran}

Tujuan pembelajaran pada materi konsep mol dicapai melalui kegiatan observasi, hipotesis, koleksi dan organisasi data, serta menarik kesimpulan. Tujuan pembelajaran pada materi konsep mol adalah; 1) menjelaskan pengertian mol dari data yang diberikan; 2) menentukan massa molar suatu unsur dan senyawa yang diketahui ar/mr nya; 3) menghitung volume molar gas yang diketahui molnya; 4) menentukan rumus empiris dari suatu senyawa jika diketahui massa dan persentase unsur-unsur penyusunnya; 5) menentukan rumus molekul dari suatu senyawa jika diketahui rumus empirisnya; 6) menentukan rumus senyawa hidrat jika massa senyawa hidrat diketahui; 7) menghitung kadar zat (persen, ppm, molaritas, molalitas dan fraksi mol) dengan tepat.

\section{Tahap design}

Tahap design (perancangan) bertujuan untuk merancang Modul yang akan dikembang kan. Langkah-langkah yang dilakukan dalam tahap design (perancangan) adalah melakukan wawancara dengan beberapa siswa SMA di kota Padang. Wawancara ini bertujuan untuk mengetahui bahan ajar yang diinginkan oleh siswa sehingga dapat membantu mereka dalam memahami materi pelajaran, terutama pada materi konsep mol. Hasil wawancara menunjuk kan bahwa siswa mengharapkan bahan ajar disajikan dengan menggunakan bahasa yang baik dan mudah dimengerti, disusun secara runtut, simpel, berwarna serta bergambar.

Modul konsep mol yang telah dirancang terdiri dari; 1) kover, 2) kata pengantar, 3) daftar 
isi, 4) daftar gambar, 5) kompetensi inti, 6) kompetensi dasar, 7) indikator, 8) tujuan pembelajaran, 9) petunjuk penggunaan modul, 10) pendahuluan, 11) peta konsep, 12) lembar kegiatan, 13) lembar kerja siswa, 14) kunci lembar kerja siswa, 15) latihan, 16) lembar evaluasi, 17) kunci lembar evaluasi, 18) kepustakaan. Kover modul, lembar kerja, dan kunci lembar kerja berturut-turut diamati pada Gambar 1 sampai Gambar 3.
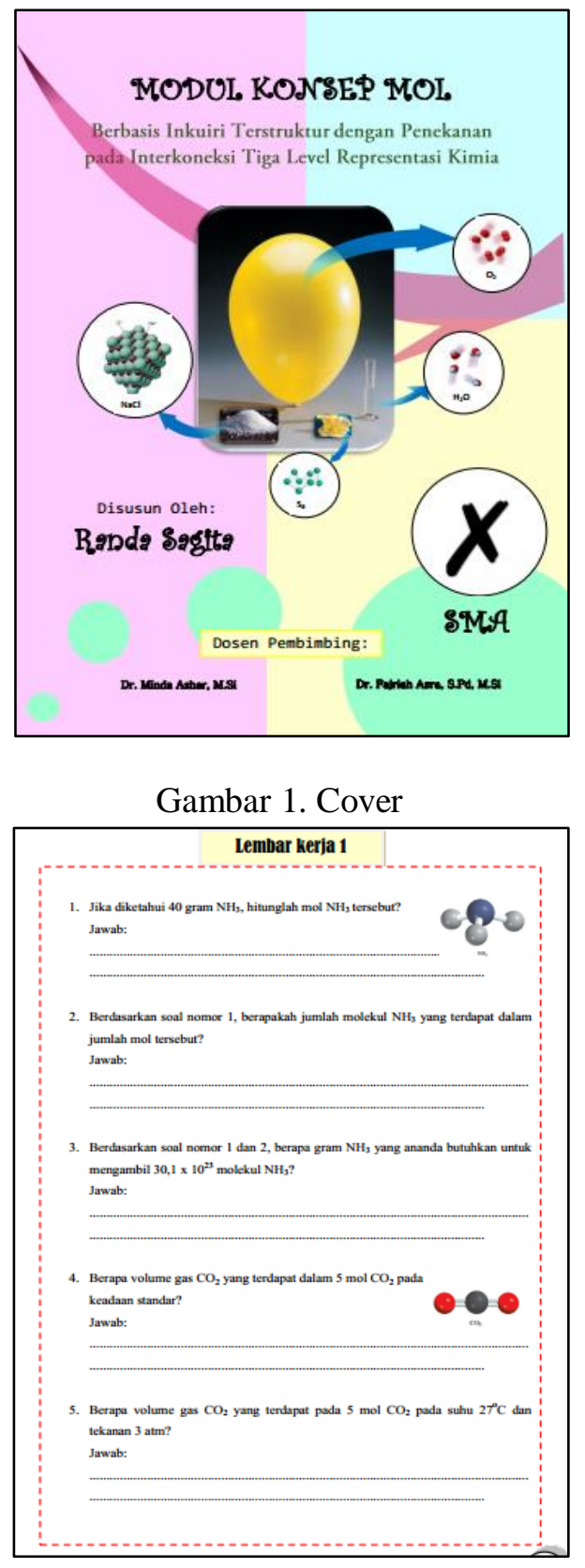

Gambar 2. Lembar Kerja

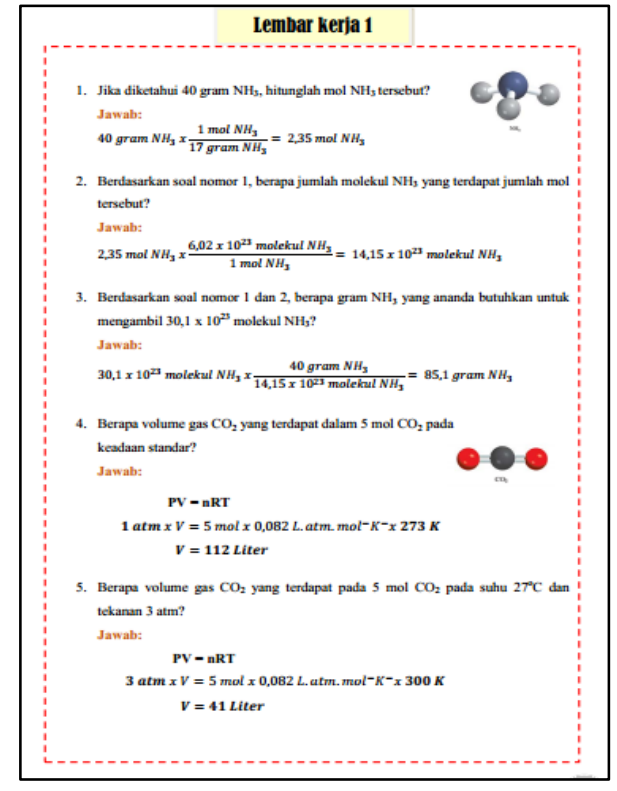

Gambar 3. Kunci Lembar Kerja

\section{Tahap Develop}

Tahap develop (pengembangan) ini bertujuan untuk menghasilkan modul konsep mol berbasis inkuiri terstruktur dengan penekanan pada interkoneksi tiga level representasi kimia yang valid dan praktis digunakan.

\section{a. Uji Validitas}

Uji validitas bertujuan untuk mengungkap kan validitas dari modul yang dikembangkan. Validasi dilakukan oleh tiga orang dosen dan dua orang guru kimia. Tahap revisi bertujuan untuk memperbaiki modul yang dianggap masih kurang tepat oleh validator sebelum produk diujicoba. Modul yang sudah diperbaiki kemudian diberikan kembali kepada validator untuk didiskusikan lebih lanjut sebelum diujicoba. Revisi dihentikan apabila validator sudah menyatakan modul yang dibuat sudah valid.

\section{b. Uji Praktikalitas}

Uji praktikalitas produk dilakukan kepada guru dan siswa SMAN 4 Padang kelas XI MIA 5. Uji praktikalitas ini bertujuan untuk mengetahui praktikalitas modul konsep mol yang dikembangkan meliputi manfaat, kemudahan penggunaan, dan efisiensi waktu pembelajaran dengan menggunakan modul tersebut. Kepraktisan modul dilakukan dengan menggunakan angket praktikalitas. 


\section{Pembahasan}

\section{Validitas Modul}

Validitas modul konsep mol yang dikembangkan memiliki nilai moment kappa sebesar 0,95 dengan kategori kevalidan sangat tinggi. Adapun penilaian validator terhadap keempat komponen modul adalah sebagai berikut:

Komponen kelayakan isi modul memiliki moment kappa sebesar 0,94 dengan kategori kevalidan sangat tinggi. Hal ini menunjukkan bahwa modul yang dikembangkan sudah sesuai dengan tuntutan kompetensi inti dan kompetensi dasar. Pertanyaan yang terdapat dalam modul sudah sesuai dengan tujuan pembelajaran yang ingin dicapai dan mengarahkan siswa untuk menemukan konsep. Selain itu, materi konsep mol telah disajikan dengan penekanan pada interkoneksi tiga level representasi kimia. Multipel representasi dapat digunakan dalam mempelajari suatu konsep yang rumit dengan penggunaan diagram, grafik, dan persamaan sehingga mempermudah proses pembelajaran (Ainsworth, 2008). Informasi, gambar-gambar, dan langkah-langkah yang disediakan membantu siswa dalam membangun model mental. Model mental siswa dapat dibangun melalui pengalaman, interpretasi, dan penjelasan mereka ketika dilibatkan dalam proses pembelajaran. Pengembangan model mental ini diperlukan untuk membuat prediksi, menguji gagasan baru, dan menyelesaikan masalah dalam pembelajaran kimia (Halim, 2013). Selain itu latihan yang diberikan dalam modul merupakan aplikasi langsung dari konsep yang dipelajari.

Komponen penyajian modul memiliki moment kappa sebesar 0,95 dengan kategori kevalidan sangat tinggi. Hal ini menunjukkan bahwa pada modul yang dikembangkan sudah disusun secara sistematis mulai dari judul, standar kompetensi, kompetensi dasar, indikator dan sesuai dengan tahapan inkuiri terstruktur yaitu observasi, hipotesis, koleksi dan organisasi data, dan kesimpulan. Pembelajaran inkuiri terstruktur membimbing siswa untuk menemu kan konsep dengan mengembangkan kemampu an dasarnya dalam penyelidikan (Zion, 2012). Sebuah modul hendaknya menampilkan kompetensi-kompetensi yang akan dikuasai oleh peserta didik dalam kegiatan pembelajaran (Daryanto, 2014).
Komponen kebahasaan modul memiliki moment kappa sebesar 0,96 dengan kategori kevalidan sangat tinggi. Hal ini menunjukkan bahwa pada modul yang dikembangkan menggunakan bahasa yang baik dan benar menurut kaidah bahasa Indonesia serta mudah dipahami. Selain itu pertanyaan-pertanyaan yang diajukan di dalam modul sudah jelas dan konsisten dalam menggunakan simbol dan lambang sehingga diharapkan dapat membantu siswa memahami materi konsep mol dengan baik.

Hal ini sesuai dengan tujuan penggunaan modul. Modul akan bermakna jika penggunanya dapat menggunakan dengan mudah. Modul harus disajikan dengan menggunakan bahasa yang mudah dimengerti, menarik dan dilengkapi ilustrasi (Depdiknas, 2008). Modul yang baik bersifat user friendly (Daryanto, 2014). Penggunaan bahasa yang baik dan benar serta mudah dimengerti adalah salah satu bentuk penerapan user friendly.

Komponen kegrafikkan memiliki moment kappa sebesar 0,97 dengan kategori kevalidan sangat tinggi. Hal ini menunjukkan bahwa pada modul yang dikembangkan telah menggunakan gambar yang dapat diamati dengan jelas, tata letak yang sesuai, yaitu berhubungan dengan ukuran huruf, jenis huruf, spasi, tampilan cover, tata letak isi modul, dan penempatan ilustrasi gambar. Nilai momen kappa secara keseluruhan dapat dilihat dari Tabel 2.

Tabel 2. Tabel Moment Kappa Validitas

\begin{tabular}{|c|c|c|c|}
\hline No & $\begin{array}{c}\text { Aspek yang } \\
\text { dinilai }\end{array}$ & $\begin{array}{c}\text { Rata-rata } \\
\text { momen } \\
\text { kappa }\end{array}$ & $\begin{array}{c}\text { Kategori } \\
\text { kevalidan }\end{array}$ \\
\hline 1 & $\begin{array}{c}\text { Komponen } \\
\text { Kelayakan } \\
\text { Isi }\end{array}$ & 0,94 & Sangat Tinggi \\
\hline 2 & $\begin{array}{c}\text { Komponen } \\
\text { Penyajian }\end{array}$ & 0,95 & Sangat Tinggi \\
\hline 3 & $\begin{array}{c}\text { Komponen } \\
\text { Kebahasaan }\end{array}$ & 0,96 & Sangat Tinggi \\
\hline 4 & $\begin{array}{c}\text { Komponen } \\
\text { Kegrafisan }\end{array}$ & 0,97 & Sangat Tinggi \\
\hline
\end{tabular}

Pada Tabel 2 dapat dilihat bahwa semua aspek yang dinilai menunjukkan nilai moment kappa besar dari 0,81. Nilai moment kappa 0,811.00 memiliki kevalidan sangat tinggi sehingga modul yang dikembangkan dinyatakan sudah valid (Sugiyono, 2013). Suatu produk dikatakan valid jika produk tersebut dapat menunjukkan 
suatu kondisi yang sudah sesuai dengan isi dan konstruknya (Arikunto, 2008).

\section{Praktikalitas Modul}

Praktikalitas modul dinilai oleh 2 orang guru kimia dan 28 orang siswa SMA kelas XI. Penilaian praktikalitas oleh guru diperoleh momen kappa sebesar 0,89 dengan kepraktisan sangat tinggi dan oleh siswa sebesar 0,91 dengan kepraktisan sangat tinggi. Praktikalitas yang dinilai terdiri atas tiga komponen yaitu kemudahan penggunaan, efisiensi waktu pembelajaran dan manfaat.

Komponen kemudahan penggunaan modul memiliki moment kappa sebesar 0,90 untuk guru dan 0,91 untuk siswa dengan kategori kepraktisan sangat tinggi. Hal ini menunjukkan Modul menggunakan bahasa yang mudah dipahami, pertanyaan-pertanyaannya jelas, materi disampaikan dengan sederhana. Modul hendaknya disusun dengan kalimat yang sederhana dan tidak membingunkan sehingga informasi yang disampaikan jelas dan tidak membingunkan (Depdiknas 2008). Selain itu ukurannya mudah dibawa.

Komponen efisiensi waktu pembelajar an memiliki moment kappa sebesar 0,86 untuk guru dan 0,88 untuk siswa dengan kepraktisan sangat tinggi. Pembelajaran dengan mengguna kan modul dapat membuat waktu pembelajaran menjadi lebih efisien dan siswa bisa belajar dengan kecepatannya masing-masing (Daryanto, 2014). Siswa dapat menggunakan modul dengan teknik yang berbeda-beda dalam memecahkan masalah dalam proses pembelajaran. Sebuah modul akan bermakna jika peserta didik dapat menggunakannya dengan mudah. Penggunaan modul dalam proses pembelajaran memungkin kan peserta didik belajar dan menyelesaikan KD lebih cepat. Modul merupakan suatu paket kurikulum yang disediakan untuk belajar sendiri (Sabri, 2010). Selain itu, modul konsep mol dirancang dengan penekanan pada interkoneksi tiga level representasi kimia. Interkoneksi dari ketiga level representasi tersebut adalah salah satu kunci untuk pengajaran kimia (gilbert and treagust, 2009). Proses pembelajaran akan menjadi lebih efektif dan efisien.

Komponen manfaat memiliki moment kappa sebesar 0,90 untuk guru dan 0,93 untuk siswa dengan kategori kepraktisan sangat tinggi. Hal ini menunjukkan modul konsep mol yang dikembangkan dapat membantu siswa dalam menemukan konsep. Latihan yang diberikan memungkinkan siswa memiliki kesempatan melatih diri mereka belajar secara mandiri. Adanya kunci jawaban dari setiap pertanyaan yang terdapat pada latihan membantu siswa mengetahui kemampuan dan tingkat pe mahamannya. Modul juga didesain sedemikian rupa sehingga menarik perhatian dan minat belajar siswa. Penggunaan warna dan desain pada bahan ajar dapat meningkatkan motivasi belajar siswa (Yusuf, 2011). Secara keseluruhan nilai momen kappa yang diberikan guru dan siswa dapat dilihat pada Tabel 3.

Tabel 3. Tabel Momen Kappa Praktikalitas

\begin{tabular}{|c|c|c|c|}
\hline No & $\begin{array}{c}\text { Aspek yang } \\
\text { dinilai }\end{array}$ & $\begin{array}{c}\text { Rata-rata } \\
\text { moment } \\
\text { kappa } \\
\text { (Guru) }\end{array}$ & $\begin{array}{c}\text { Rata-rata } \\
\text { moment } \\
\text { kappa } \\
\text { (Siswa) }\end{array}$ \\
\hline 1 & $\begin{array}{c}\text { Komponen } \\
\text { Kemudahan } \\
\text { Penggunaan }\end{array}$ & 0,90 & 0,91 \\
\hline 2 & $\begin{array}{c}\text { Komponen } \\
\text { Efisiensi } \\
\text { Waktu }\end{array}$ & 0,86 & 0,88 \\
\hline 3 & $\begin{array}{c}\text { Komponen } \\
\text { Manfaat }\end{array}$ & 0,90 & 0,93 \\
\hline
\end{tabular}

Berdasarkan hal di atas, diketahui bahwa modul yang dikembangkan memudahkan guru dan siswa dalam proses pembelajaran dan mencapai tujuan pembelajaran. Hal ini sesuai dengan fungsi bahan ajar yaitu menjadi pedoman bagi guru dan bagi siswa, mengerah kan semua aktivitas siswa dalam pembelajaran, serta alat evaluasi pencapaian hasil belajar (Hamdani, 2010). Modul bermanfaat untuk mewujudkan proses pembelajaran yang ber kualitas, mengkondisikan kegiatan pembelajaran lebih terencana, mandiri, tuntas dan dengan hasil yang jelas (Daryanto, 2014).

\section{KESIMPULAN}

Berdasarkan penelitian yang telah dilakukan, dihasilkan modul konsep mol berbasis inkuiri terstruktur dengan penekanan pada interkoneksi tiga level representasi kimia untuk kelas X SMA menggunakan model pengembangan 4-D. Modul yang dikembangkan mempunyai tingkat kevalidan dan kepraktisan sangat tinggi baik oleh guru dan siswa.

\section{DAFTAR PUSTAKA}

Ainsworth, Shaaron. 2008. The Educational Value of Multiple-representations when Learning Complex Scientific Concept. J.K 
Gilbert et al., (eds.), Visualization: Theory and Practice in Science Education, 191208. Springer 2008.

Arikunto, S. 2008. Dasar-Dasar Evaluasi Pendidikan. Jakarta: Bumi Aksara.

Arinigsih, Ismi, dkk. 2014. "Pengembangan Panduan Praktikum Kimia Berbasis Inkuiri Terstruktur di Kelas XII SMAN 1 Indralaya Utara". Program Studi Pendidikan Kimia, FKIP, Universitas Sriwijaya.

Bell, Randy. L, dkk. 2005. Simplifying Inquiry Instruction. The Science Teacher.

Boslaugh, Sarah dan Paul A. W. 2008. Statistics in a Nutshell, a desktop quick reference. Beijing, Cambridge, Famham, Köln, Sebastopol, Taipei,Tokyo: O'reilly.

Budiningsih, Asri. 2012. Belajar \& Pembelajaran. Jakarta: PT Rineka Cipta.

Brady, James E. 2012. Chemistry The Molecular Nature of Matter. New York: John Wiley \& Sons, Inc.

Chittleborough, G., Treagust, D. F., Mocerino, M. 2002. Constraints to the Development of FirtsYear University Chemistry Students' Mental Model of Chemical Phenomena. Presented at the 11th Annual Teaching and Learning Forum for Western Australian Universities, Edith Cowan Universty, Australia.

Colburn, Alan. 2000. An inquiry Primer. Science Scope, Maret 2000.

Daryanto. 2014. Pengembangan Perangkat Pembelajaran. Yogyakarta: PT Gava Media.

Depdiknas. 2008. Panduan Pengembangan Bahan Ajar. Direktorat Jendral Manajemen Pendidikan Dasar dan Menengah, Tahun 2008.

Gilbert, John K dan David F.Treagust. 2009. Introduction: Macro, Submicro, and Symbolic Representations and the Relationship Between Them: Key Model in Chemical Education. Springer Science+Business Media.

Halim N. D. A., Ali Moh. B., Yahaya N., Said Mohd. N. H. M S. 2013. Mental Model in Learning Chemical Bonding: A preliminary study, Procedia-Social and Behavioral Sciences 97, Hal. 224-228.
Hamdani. 2010. Strategi Belajar Mengajar. Bandung: Pustaka Setia.

Kurniasih, Imas dan Berlin Sani. 2014. Sukses Mengimplementasikan Kurikulum 2013. Yogyakarta: Kata Pena.

Maryati, Anita Mariana. 2015. "Lembar Kerja (LKS) Eksperimen dan Non-Eksperimen Berbasis Inkuiri Terstruktur yang dikembangkan pada Subpokok Materi Pergeseran Kesetimbangan Kimia”. Prosiding Simposium Inovasi dan Pembelajaran Sains 2015.

Sabri, Ahmad. 2010. Strategi Belajar Mengajar. Bandung: Ciputat Press.

Schmid, Sarah and Franz X. Bogner. 2015. Effect of Students' Effort Scores in a Structured Inquiry Unit on Long-Term Recall Abilities of Content Knowledge. Germany. Hindawi Publishing Corporation. Education Research International. Research Article.

Schnotz, Wolfgang and Maria Bannert. 2003. Construction and Interference in Learning from Multiple Representation. Elsevier Science Ltd.

Sugiarto. 2015. Peningkatan Hasil Belajar Materi Getaran dan Gelombang Melalui Pembelajaran Inkuiri Terstruktur. Didaktikum: Jurnal Penelitian Tindakan Kelas. Vol.16. No. 4.

Sugiyono. 2013. Metode Penelitian Kuantitatif Kualitatif dan $\mathrm{R} \& \mathrm{D}$. Bandung: ALFABETA.

Sunyono. 2013. Efektifitas Model Pembelajaran Berbasis Multipel Representasi Dalam Membangun Model Mental Mahasiswa Topik Stoikiometri Reaksi. Jurnal Pendidikan Progresif . Vol.3. No. 1. Hlm. 65-79.

Trianto. 2014. Model Pembelajaran Terpadu. Jakarta: Bumi Aksara.

Yusus, Samsu dan Nani Sugandhi. 2011. Perkembangan Peserta Didik. Jakarta: PT Raja Grafindo Persada.

Zion, Michal dan Ruthy Mendelovici. 2012. Moving from Structured to Open Inquiry: Challenges and Limits. Science Education Internasional. Vol.23, No.4. Hlm. 383-399. 